\title{
Relationship between Thyroid Volume and lodine, Leptin, and Adiponectin in Obese Women before and after Weight Loss
}

\author{
Esin Eray $^{\mathrm{a}}$ Funda Sari $^{\mathrm{b}}$ Sabahat Ozdem ${ }^{\mathrm{c}}$ Ramazan Sari ${ }^{\mathrm{a}}$ \\ ${ }^{a}$ Division of Endocrinology and Metabolism, School of Medicine, Akdeniz University, ${ }^{\circ}$ Division of Nephrology, \\ Antalya Education and Research Hospital, Ministry of Health, and ' Department of Clinical Chemistry, School of \\ Medicine, Akdeniz University, Antalya, Turkey
}

\section{Key Words}

Adiponectin $\cdot$ lodine $\cdot$ Leptin $\cdot$ Thyroid volume $\cdot$ Weight loss

\begin{abstract}
Objective: To investigate whether or not reduction of thyroid volume during weight loss is related to adipocytokines and urinary iodine excretion in obese women. Subjects and Methods: 98 obese and 31 non-obese women consecutively admitted to the endocrinology and metabolism outpatient clinic of the School of Medicine, Akdeniz University were included in the study. Thyroid volume, thyroid function tests, leptin and adiponectin levels, and urinary iodine excretion were measured at baseline and six months after treatment for obesity. Results: Thyroid volume increased in obese women $(p=0.048)$. After adjustment for body mass index, there were no significant differences in plasma leptin and serum adiponectin levels between obese and non-obese women $(p>0.05)$. Thyroid volume correlated positively with body mass index $(r=0.48, p=0.04)$, leptin $(r=0.1, p=0.03)$, and thyroid-stimulating hormone $(r=0.43, p=0.001)$ levels, while there was a negative correlation between thyroid volume and urinary iodine $(r=-0.38, p=0.04)$ and urinary iodine/creatinine ratio $(r=-0.25, p=0.045)$ in obese women. Changes in body mass index $(p=0.022)$ and leptin levels $(p=0.039)$ were the only factors that significantly affected
\end{abstract}

\section{KARGER}

Fax +4161306 1234

E-Mail karger@karger.ch

www.karger.com
(C) 2010 S. Karger AG, Basel

1011-7571/11/0201-0043\$38.00/0

Accessible online at:

www.karger.com/mpp the change of thyroid volume during weight loss. Conclusion: lodine status may play an important role in increased thyroid volume in obese women; however, iodine status did not seem to exert a significant influence on the changes in thyroid volume. On the other hand, changes in both body mass index and plasma leptin levels seemed to be important for changes in thyroid volume. Copyright $\odot 2010$ S. Karger AG, Basel

\section{Introduction}

There are conflicting data in the literature regarding the relationship between obesity and thyroid hormones or thyroid volume. Most studies have demonstrated clinically and biologically insignificant high thyroid-stimulating hormone (TSH), low tri-iodothyronine (T3), low thyroxin (T4), and increased thyroid volume in the obese population [1-3]. There are few reports about the relationship between weight loss and thyroid volume and function [4-7]. In a recent study, we reported higher goiter prevalence and increased thyroid volume in obese women and a reduction in thyroid volume after $>10 \%$ weight loss in obese women [6].

It is commonly accepted that in addition to genetic predisposition, inadequate thyroid hormone synthesis due to iodine deficiency results in cyclic TSH stimulation, 
which in time results in euthyroid goiter. Obesity may be one of the phenotypic representations of this genetic presentation, as our recent study revealed higher goiter prevalence in obese women [8].

Cytokines secreted by adipocytes such as leptin and adiponectin have been shown to be related to thyroid function in some studies [9-12]. Leptin has been reported to be critical for normal function of the thyroid axis in humans [9-11]. Similarly, a study showed that circulating adiponectin modulates insulin action and the hypothalamo-thyroidal axis [12]. The relationships between thyroid function-volume and leptin or adiponectin levels are still controversial [9-15]. Furthermore, to our knowledge, the relationship between reduced thyroid volume and adipocytokine levels during weight loss has not yet been studied. Hence, in this study, we first aimed to evaluate the relationships of baseline thyroid volume and thyroid hormone levels with iodine status, and plasma leptin and serum adiponectin levels. Second, we aimed to investigate whether reduction of thyroid volume during weight loss is related to adipocytokines and urinary iodine excretion in obese women.

\section{Subjects and Methods}

We evaluated 98 consecutive obese [body mass index (BMI): $30 \mathrm{~kg} / \mathrm{m}^{2}$ ] premenopausal women, mean age $40.5 \pm 11.4$ years, and 31 non-obese (BMI ranging between 20 and $25 \mathrm{~kg} / \mathrm{m}^{2}$ ) women, mean age $38.6 \pm 13$ years, who were admitted to our endocrinology outpatient clinic. Informed consent was obtained from the subjects. Approval was obtained from the ethics committee of Akdeniz University Medical Faculty. All subjects were measured for weight $(\mathrm{kg})$, height $(\mathrm{m})$ and BMI $\left(\mathrm{kg} / \mathrm{m}^{2}\right)$. Subjects with a history of thyroid disease or positive thyroid auto-antibody or those taking thyroid hormones, anti-thyroidal drugs, or iodine-containing drugs were excluded.

Thyroid function tests, plasma leptin and serum adiponectin levels, and urinary iodine excretion were measured and thyroid ultrasonography was performed at baseline. All obese women had difficulty with diet and exercise and were given medication for obesity: 50 patients were given sibutramine $15 \mathrm{mg} /$ day and the remaining 48 orlistat $360 \mathrm{mg} /$ day. The biochemical parameters mentioned above were reassessed 6 months after the obesity treatment.

Serum TSH, free T3 and free T4 were analyzed with Roche Modular Analytics E170 immunoassay system (Roche Diagnostics, Mannheim, Germany) using electrochemiluminescence immunoassay method (ECLIA). Intra- and inter-assay coefficient of variation for these assays were 1.9 and $2.2 \%$ for TSH, 1.3 and $2.1 \%$ for free T3, and 1.4 and $2.7 \%$ for free T4, respectively. Fasting plasma leptin levels were measured by two-site immunoradiometric assay method (Active Human Leptin IRMA, DSL-23100). Serum adiponectin levels were measured using commercial ELISA kit (Linco Research, St. Charles, Miss, USA).
Table 1. Baseline values in non-obese controls and obese patients

\begin{tabular}{lclc}
\hline & $\begin{array}{l}\text { Non-obese } \\
(\mathrm{n}=31)\end{array}$ & $\begin{array}{l}\text { Obese } \\
(\mathrm{n}=98)\end{array}$ & $\begin{array}{l}\mathrm{p} \\
\text { value }\end{array}$ \\
\hline Age, years & $38.6 \pm 12.9$ & $40.5 \pm 11.4$ & 0.46 \\
$\mathrm{BMI}, \mathrm{kg} / \mathrm{m}^{2}$ & $23.1 \pm 1.9$ & $38.6 \pm 5.4$ & $<0.001$ \\
Leptin, $\mathrm{ng} / \mathrm{ml}$ & $23.0 \pm 11.9$ & $67.1 \pm 29.3$ & $<0.001$ \\
Adiponectin, ng/ml & $31.5 \pm 14.2$ & $18.7 \pm 13.6$ & 0.042 \\
TSH, $\mu \mathrm{IU} / \mathrm{ml}$ & $1.97 \pm 1.1$ & $1.9 \pm 1.1$ & 0.74 \\
Free T4, ng/dl & $1.3 \pm 0.16$ & $1.25 \pm 0.17$ & 0.34 \\
Free T3, pg/dl & $3.1 \pm 0.46$ & $3.0 \pm 0.43$ & 0.61 \\
Urinary iodine, $\mu \mathrm{g} / \mathrm{l}$ & & & \\
$\quad$ Median & $160(60-300)$ & $170(70-310)$ & 0.6 \\
Urinary iodine/creatinine & & & \\
$\quad$ Median & $215(90-380)$ & $205(85-375)$ & 0.5 \\
Thyroid volume, ml & $23.9 \pm 7.6$ & $31.4 \pm 11.1$ & 0.048 \\
\hline
\end{tabular}

Sensitivity was $0.78 \mathrm{ng} / \mathrm{ml}$, and the intra- and inter-assay variability were 1.8 and $6.2 \%$, respectively. Urinary iodine concentration was determined by a modified Sandell-Kolthoff reaction method, using a urinary iodine assay kit (Bioclone, Hitachi Chemical). The intra- and inter-assay variability were 3.0 and $3.4 \%$, respectively [16].

Thyroid ultrasonography was performed (high-resolution real-time ultrasonographic scanner, $7.5 \mathrm{MHz}$ probe; Toshiba, Tokyo, Japan) by the same investigator (R.S.) in all the patients with the patient in the supine position with a hyperextended neck. Thyroid volume was expressed in $\mathrm{ml}$ and the sum of both lobes was calculated by multiplying the length, width and thickness of each lobe with a corrective factor (0.479) [17]. Existing goiter was defined as a thyroid volume above $18 \mathrm{ml}$ [18].

\section{Statistical Analyses}

Statistical analyses were performed by SPSS statistical software (SPSS v. 10.0, Cary, N.C., USA). Continuous variables were tested for normality according to the Kolmogorov-Smirnov test. The results were presented as means \pm standard deviation if distribution was normal or median (minimum-maximum) if distribution was abnormal. Values of the parameters at baseline and after 6 months were compared by paired t test (if distribution was normal) and Wilcoxon signed ranks test. One-way ANOVA was used to compare the parameters between the groups. Univariate analysis of variance was used to detect the factors that affected thyroid volume. Spearman test was used for correlation analysis. $\mathrm{p}<0.05$ was considered statistically significant.

\section{Results}

The baseline plasma leptin level $(\mathrm{p}<0.001)$, serum adiponectin level $(\mathrm{p}=0.042)$ and thyroid volumes $(\mathrm{p}=$ 0.048 ) differed significantly between the control and obese patients (table 1). However, after adjustment for 


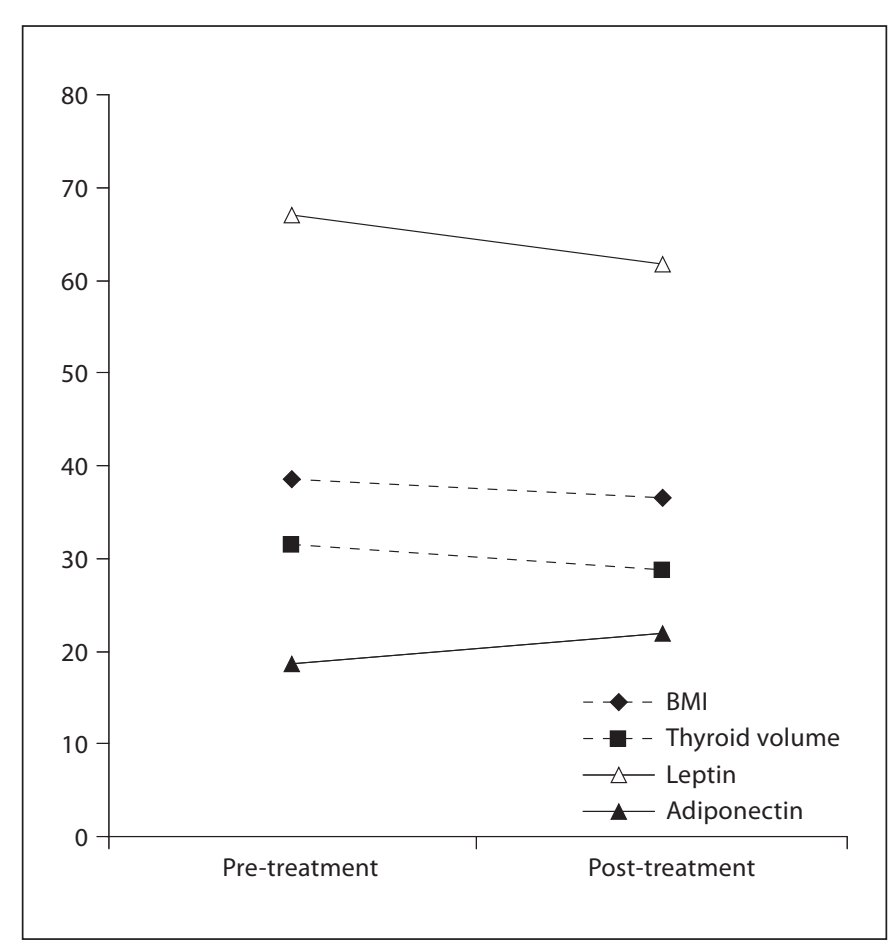

Fig. 1. Changes in measured parameters after 6 months of treatment for obesity ( $p$ values $<0.001$ for BMI, 0.013 for leptin, 0.018 for adiponectin and $<0.001$ for thyroid volume).

BMI, there was no significant difference in leptin and adiponectin levels between these two groups. The thyroid volume correlated positively with $\mathrm{BMI}(\mathrm{r}=0.48, \mathrm{p}=0.04)$, leptin level $(\mathrm{r}=0.1, \mathrm{p}=0.03)$ and TSH level $(\mathrm{r}=0.43, \mathrm{p}=$ $0.001)$ in obese women. In contrast, it correlated negatively with urinary iodine $(\mathrm{r}=-0.38, \mathrm{p}=0.04)$, and urinary iodine/creatinine ratio $(\mathrm{r}=-0.25, \mathrm{p}=0.045)$.

There were no statistically significant changes in TSH, free T3, free T4, urinary iodine and urinary iodine/creatinine levels during the study period ( $p>0.05)$. After six months of obesity treatment, BMI ( $p<0.001)$, thyroid volume $(\mathrm{p}<0.001)$ and leptin level $(\mathrm{p}=0.013)$ were decreased, whereas adiponectin level $(\mathrm{p}=0.018)$ increased significantly compared with baseline values (fig. 1). The reduction in thyroid volume correlated positively $(\mathrm{r}=$ $0.56, \mathrm{p}=0.02$ ) with the reduction in BMI in obese patients. The results of the univariate analysis of variance revealed that the changes in BMI $(\mathrm{p}=0.022)$ and leptin level $(p=0.039)$ were the only factors significantly affecting the changes in thyroid volume.

\section{Discussion}

The primary aim of the present study was to determine whether factors such as iodine status, leptin and adiponectin levels affect the increased thyroid volume in obese women. Increased thyroid volume in obese women can be explained by several factors including thyroid autoimmunity, iodine status, genetic predisposition, obesity-related protein or cytokines [2]. Since 1998, a mandatory iodination program has been implemented in Turkey. Although our obese patients were not iodine-deficient, there was a negative relationship between thyroid volume and urinary iodine levels in these patients. Therefore, in contrary to findings of Stichel et al. [19], iodine status may play an important role in the increased thyroid volume in obese women.

The relationships between thyroid function or volume and plasma leptin or serum adiponectin levels are still controversial [9-15]. Circulating leptin and adiponectin have been reported to be critical for normal function of the thyroid axis [8-12]. For example, leptin stimulates biosynthesis of thyrotropin-releasing hormone in vitro and influences the activity of the hypothalamic-pituitary-thyroid axis in vivo. Moreover, the detection of a leptin receptor in the pituitary gland has raised the possibility that circulating leptin might also act directly to modulate TSH release [20,21]. In contrast to our results, Iacobellis et al. [13] reported that adiponectin and leptin were associated with TSH in obese euthyroid women. The association between TSH and leptin could be an adaptive response to the high thermogenesis due to the increased amount of fat in obese patients [22]. On the other hand, Gomez et al. [9] reported no correlation between leptin levels and pituitary-thyroid axis, but noted a positive correlation between leptin and thyroid volume. The lack of harmony amongst different results may be related to the study designs and patient populations. We found positive correlations between thyroid volume and BMI, TSH and leptin levels in obese women. Although obese women had high leptin and low adiponectin levels compared to non-obese ones, there were no significant differences between the two groups after adjusting for BMI. Therefore, it might be concluded that these differences may rather be due to obesity instead of increased thyroid volume.

The mechanism for change in thyroid volume during weight loss is not clearly understood. Although we found significant relationships between increased thyroid volume and iodine status in obese women, the decrease in thyroid volume during weight loss was not associated sig- 
nificantly with iodine status, which indicated that while iodine status may play an important role for increased thyroid volume in obese women, it does not affect changes in thyroid volume.

The relationship between reduction in thyroid volume and adipocytokine levels during weight loss has not yet been adequately defined. The present study, in agreement with others [23-25], found a significant decrease in leptin and increase in adiponectin levels during weight loss. Serum leptin levels also correlated positively with the reduction in thyroid volume. Furthermore, it was found that changes in BMI and leptin levels were the sole factors affecting the changes in thyroid volume in obese women.

\section{Conclusion}

The findings of the present study show that iodine status may play an important role for increased thyroid volume in obese women; however, it does not significantly affect the change in thyroid volume. On the other hand, changes in BMI and leptin levels are significantly related to changes in thyroid volume.

\section{References}

$\checkmark 1$ Hegedus L, Perrild H, Poulsen LR, Andersen JR, Holm B, Schnohr P, Jensen G, Hansen JM: The determination of thyroid volume by ultrasound and its relationship to body weight, age, and sex in normal subjects. J Clin Endocrinol Metab 1983;56:260-263.

-2 Semiz S, Senol U, Bircan O, Gumuslu S, Bilmen S, Bircan I: Correlation between age, body size and thyroid volume in an endemic area. J Endocrinol Invest 2001;24:559-563.

>3 Gomez JM, Maravall FJ, Gómez N, Gumà A, Soler J: Determinants of thyroid volume as measured by ultrasonography in healthy adults randomly selected. Clin Endocrinol (Oxf) 2000;53:629-634.

$\checkmark 4$ Buscemi S, Verga S, Maneri R, Blunda G, Galluzzo A: Influences of obesity and weight loss on thyroid hormones: a 3- to 3.5-year follow-up study on obese subjects with surgical bilio-pancreatic by-pass. J Endocrinol Invest 1997;20:276-281.

5 Yashkov YI, Vinnitsky LI, Poroykova MV, Vorobyova NT: Some hormonal changes before and after vertical banded gastroplasty for severe obesity. Obes Surg 2000;10:48-53.

-6 Sari R, Balci MK, Altunbas H, Karayalcin U: The effect of body weight and weight loss on thyroid volume and function in obese women. Clin Endocrinol (Oxf) 2003;59:258-262.

$\checkmark 7$ Wesche MF, Wiersinga WM: Relation between lean body mass and thyroid volume in competition rowers before and during intensive physical training. Horm Metab Res 2001;33:423-427.

8 Greenspan FS: The thyroid gland; in: Greenspan FS, Gardner DG (eds): Basic and Clinical Endocrinology. San Francisco, McGraw-Hill, 2001, pp 254-255.

-9 Gomez JM, Maravall FJ, Gomez N, Guma A, Casamitjana R, Soler J: Pituitary-thyroid axis, thyroid volume and leptin in healthy adults. Horm Metab Res 2002;34:67-71.
10 Pinkney JH, Goodrick SJ, Katz J, Johnson AB, Lightman SL, Coppack SW, MohamedAli V: Leptin and the pituitary-thyroid axis: a comparative study in lean, obese, hypothyroid and hyperthyroid subjects. Clin Endocrinol (Oxf) 1998;49:583-588.

11 Naslund E, Andersson I, Degerblad M, Kogner P, Kral JG, Rossner S, Hellstrom PM: Associations of leptin, insulin resistance and thyroid function with long-term weight loss in dieting obese men. J Intern Med 2000;248: 299-308.

12 Yaturu S, Prado S, Grimes SR: Changes in adipocyte hormones leptin, resistin, and adiponectin in thyroid dysfunction. J Cell Biochem 2004;93:491-496.

13 Iacobellis G, Ribaudo MC, Zappaterreno A, Iannucci CV, Leonetti F: Relationship of thyroid function with body mass index, leptin, insulin sensitivity and adiponectin in euthyroid obese women. Clin Endocrinol (Oxf) 2005;62:487-491.

14 Santini F, Marsili A, Mammoli C, Valeriano R, Scartabelli G, Pelosini C, Giannetti M, Centoni R, Vitti P, Pinchera A: Serum concentrations of adiponectin and leptin in patients with thyroid dysfunctions. J Endocrinol Invest 2004;27:RC5-RC7.

15 Iglesias P, Alvarez Fidalgo P, Codoceo R, Diez JJ: Serum concentrations of adipocytokines in patients with hyperthyroidism and hypothyroidism before and after control of thyroid function. Clin Endocrinol (Oxf) 2003;59:621-629.

16 Sandel EB, Kolthoff IM: Microdetermination of iodine by a catalytic method. Microchem Acta 1937;1:9-25.

17 Ueda D: Sonographic measurement of the volume of the thyroid gland in healthy children. Acta Paediatr Jpn 1989;31:352-354.
18 Schaaf L, Pohl T, Schmidt R, Vardali I, Teuber J, Schlote-Sauter B, Nowotny B, Schiebeler $\mathrm{H}$, Zober A, Usadel KH: Screening for thyroid disorders in a working population. Clin Invest 1993;71:126-131.

19 Stichel H, l'Allemand D, Grüters A: Thyroid function and obesity in children and adolescents. Horm Res 2000;54:14-19.

20 Ghizzoni L, Mastorakos G, Ziveri M, Furlini M, Solazzi A, Vottero A, Bernasconi S: Interactions of leptin and thyrotropin 24-hour secretory profiles in short normal children. J Clin Endocrinol Metab 2001;86:2065-2072.

-21 Mantzoros CS, Ozata M, Negrao AB, Suchard MA, Ziotopoulou M, Caglayan S, Elashoff RM, Cogswell RJ, Negro P, Liberty V, Wong ML, Veldhuis J, Ozdemir IC, Gold PW, Flier JS, Licinio J: Synchronicity of frequently sampled thyrotropin (TSH) and leptin concentrations in healthy adults and leptin-deficient subjects: evidence for possible partial TSH regulation by leptin in humans. J Clin Endocrinol Metab 2001;86: 3284-3291.

22 Melnyk A, Himms-Hagen J: Temperaturedependent feeding: lack of role for leptin and defect in brown adipose tissue-ablated obese mice. Am J Physiol 1998;274:R1131-R1135.

23 Bastard JP, Maachi M, Lagathu C, Kim MJ, Caron M. Vidal H, Capeau J, Feve B: Recent advances in the relationship between obesity, inflammation, and insulin resistance. Eur Cytokine Netw 2006;17:4-12.

24 Ronti T, Lupattelli G, Mannarino E: The endocrine function of adipose tissue: an update. Clin Endocrinol (Oxf) 2006;64:355365 .

25 Ballantyne GH, Gumbs A, Modlin IM: Changes in insulin resistance following bariatric surgery and the adipoinsular axis: role of the adipocytokines, leptin, adiponectin and resistin. Obes Surg 2005;15:692-699. 